\title{
Dari Ibrahim M. Abu Rabi' tentang Problematika Studi Islam Kontemporer
}

\author{
Hasan Mahfudh \\ STAI Sunan Pandanaran Yogyakarta \\ Email:mahfudhhasan@yahoo.co.id
}

\begin{abstract}
Abstrak
The dynamic of thought, study, and learning is a necessity. The interaction of subjects and objects, added by some problems which are being or have occurred and the challenges that will be faced become the reasons for this dynamic. It is not a problem if perspectives, approaches or scientific paradigm have shifted significantly later. Islamic study formulated in the Ulum al-din, al-Fikr al-Islamy or Dirasat Islamiyyah is ideally always dynamic and evolving as a study in general. Despite of the various problems faced by Muslims today, Ibrahim M. Abu Rabi '(hereinafter typed Abu Rabi') found no significant development of Islamic studies. Stagnation of Islamic studies at least can be found in the various elements. Through the study of Islamic thought history, Abu Rabi' tried to uncover the "disease" which was lull. Then, he tried to resuscitate the intellectuals to fully understand the role and function in encouraging Islamic studies with a scientific perspective developing at this time. The issue becoming increasingly complex cannot be explained satisfactorily by the classical Ulum al-Din theory which is only focused on text, especially only a portion of the text. Halal and haram for example are felt helpless facing increasingly varied social problems. Islamic studies would not want to open and open up to the disciplines of science, not mono-dicipline.
\end{abstract}

Dinamika pemikiran, kajian, dan studi adalah sebuah keniscayaan. Interaksi subyek dan objek, ditambah persoalan-persoalan yang sedang atau telah terjadi dan berbagai tantangan yang akan dihadapi menjadi alasan atas dinamika ini. Bukan persoalan jika selanjutnya perspektif, pendekatan, atau paradigma keilmuan mengalami pergeseran yang signifikan. Kajian Islam yang dirumuskan dalam disiplin Ulum al-din, al-Fikr al-Islamy atau Dirasat Islamiyyah idealnya selalu dinamis dan berkembang sebagaimana layaknya sebuah kajian pada umumnya. Meski berbagai persoalan tengah dihadapi umat Islam dewasa ini, Ibrahim M. Abu Rabi' (selanjutnya diketik Abu Rabi') tidak menemukan perkembangan yang signifikan dari studi Islam. Stagnansi studi Islam setidaknya dapat ditemukan dari berbagai unsur. Melalui kajian sejarah pemikiran Islam, Abu Rabi' berusaha menyingkap "penyakit" yang meninabobokan ini. Selanjutnya, ia berusaha menyadarkan para intelektual untuk memahami betul peran dan fungsinya dalam menggiatkan studi Islam dengan perspektif keilmuan 
yang berkembang saat ini. Persoalan yang kian menggurita dan semakin kompleks tidak dapat dijelaskan secara memuaskan oleh teori Ulum al-Din klasik yang hanya terfokus pada teks, terlebih hanya sebagian teks. Halal dan haram misalnya, dirasa tidak berdaya ketika menghadapi persoalan kemasyarakatan yang kian variatif. Studi Islam mau tidak mau harus terbuka dan membuka diri terhadap disiplin-disiplin keilmuan, tidak monodisiplin.

Keywords: Islamic studies, intellectual engagement, stagnation, multidisciplinary.

\section{Pendahuluan}

Meskipun dewasa ini telah banyak dibincangkan, kajian mendalam atas problematika studi Islam masih terlalu prematur untuk dianggap selesai (baca: berhasil). Peristiwa demi peristiwa yang terjadi pada dunia Muslim khususnya, atau peristiwa yang terjadi pada dunia global di mana umat Islam terkait secara aktif di dalamnya -pada kurun satu dekade lebih-setidaknya menyadarkan betapa Islam, baik dari aspek normatif-doktrinal maupun historis-empirical selalu menarik untuk diperhatikan. Kondisi tersebut tidak berlebihan mengingat bahwa kajian atas Islam terus mengalami pembaharuan yang signifikan khususnya pasca tragedi serangan 11 September 2001. Banyak ditemukan kajian khusus terkait dengan Islam pasca peristiwa tersebut, baik kajian yang dilakukan oleh umat Islam sendiri (insider) maupun oleh pemikir luar (outsider). ${ }^{1}$

Kesenjangan antara idealitas Islam sebagai agama yang cinta akan perdamaian dan berkemajuan dengan kenyataan berbagai peristiwa kekerasan dan kondisi ketertinggalan umat Islam saat ini adalah fakta yang mau tidak mau harus diselesaikan. Upaya penyelesaian atas problem tersebut sebenarnya telah beberapa kali dilakukan oleh pemikir-pemikir Islam sebelumnya, seperti Hasan Hanafi, Abed al-Jabiri, Nasr Hamd Abu Zaid dan sebagainya. Hanya saja, kajian yang dilakukan oleh mereka cenderung berkaitan dengan upaya

${ }^{1}$ Pada tahun 2004 misalnya, American Journal Of Islamic Social Science Menerbitkan satu edisi khusus terkait isu neo-orientalisme dan Islamphobia pasca 9 September 2001. Terdapat setidaknya 28 artikel yang secara spesifik mengkaji Islam pasca tragedi 9 september 2001 baik dilihat dari aspek kemanusiaan, problem gender, sosial, politik, ekonomi, bahkan media. Lihat: Katherine Bullock (ed), "Neo-Orientalism \& Islamophobia: Post -9/11", American Journal Of Islamic Social Science, (USA: International Institute of Islamic Though, 2004), Vol. XXI, No. 3. 
rekonseptualisasi teks dan turas. ${ }^{2}$ Bagi mereka, perlu pembacaan kontemporer (qira'ah muashirah) -dengan pembaruan epistemologi misalnya-terhadap teks dan turas Islam sehingga mampu menelurkan pemahaman yang komperhensif dan progresif dalam menghadapi problematika saat ini. ${ }^{3}$

Kontribusi dari pemikiran beberapa tokoh tersebut tidak dapat diragukan lagi. Akan tetapi, terdapat corak berbeda yang tampaknya dapat dilakukan dalam upaya menganalisis problematika umat Islam terkait kondisi serba "tertinggal" saat ini. Corak tersebut setidaknya dapat diperhatikan dari pemikiran Ibrahim M. Abu Rabi' yang dengan berdasarkan pada kajian sosia-historis berlandaskan kajian wawasan, Abu Rabi' berupaya mengelaborasi berbagai problematika umat Islam terkait dengan kondisi historisnya. Artikel ini berupaya mengeksplorasi pemikiran tersebut untuk kemudian direfleksikan dalam kondisi studi Islam saat ini, khususnya terkait studi Hadis.

\section{Ibrahim M. Abu Rabi’: Membaca Kegelisahan}

Julukan sebagai intelektual putra dua benua layak disematkan pada Ibrahim Abu Rabi'. Meski secara biologis terlahir di Nazaret, Galilea, Palestina pada tahun 1956, Abu Rabi' ternyata memegang kewarganegaraan ganda: Israel dan Amerika Serikat. Pengembaraan kesarjanaannya dimulai dari Universitas Bir Zit di Tepi Barat. Ia melanjutkan studi dan memperoleh gelar masternya di Universitas Chincinati dan Temple University. Adapaun gelar doktornya (Ph.D), ia dapatkan di Temple University Departement Of Religion pada 1987.4

${ }^{2}$ Turâts secara literal berarti warisan atau peninggalan (heritage, patrimoine, legacy). Dalam ranah pemikiran kontemporer, turâts adalah kekayaan tradisi kebudayaan dan khazanah intelektual yang diwariskan oleh para pendahulu. Turâts merupakan warisan tradisi masa lalubaik masa lalu yang jauh atau dekat-yang hadir di tengah-tengah kita dan menyertai kekinian kita. Nomenklatur turâts merupakan asli produk wacana Arab kontemporer, dan tidak ada equivalent atau padanan yang tepat dalam literatur bahasa Arab klasik untuk mewakili istilah tersebut. Lihat: M. Abed al-Jabiri, al-Turats wa al-Hadatsah (Beirut: Markaz Dirasat al-Wihdah alArabiyah, 1991), h. 23. Bandingkan: Hasan Hanafi, al-Turats wa al-Tajdid cet. IV (Kairo: alMu'assasah al-Jami'iyah li al-Dirasat wa al-Nasyr wa al-Tauzi', 1992), h. 13.

${ }^{3}$ Sebagai contoh, al-Jabiri menawarkan model pembacaan alternatif yang kemudian disebut dengan qira'ah mu'ashirah (pembacaan kontemporer) dengan jargon ja'lu al-maqru' mu'ashiran li nafsih wa mu'ashiran lana. Metode pembacaan tersebut meniscayakan dua langkah; fashl al-maqru' 'an al-qari' dan washl al-qari' 'an al-maqru'. M. Abed al-Jabiri, Nahnu wa al-Turats: Qira'ah Mu'ashirah fi Turatsina al-Falsafi cet. VI (Beirut: al-Markaz al-Tsaqafi al-Arabi, 1993), h. 12.

${ }^{4}$ Bandingkan: Nasiruddin, "Metodologi Studi Agama Perspektif Arkoun dan Ibrahim M. Abu Rabi””, dalam M Arfan Mu'ammar (dkk), Studi Islam (Yogyakarta: IRCiSod, 2011), h. 157. 
Setelah mendapatkan gelar akademiknya sebagi guru besar studi Islam dan pernah menjabat co-Direktur Pusat MacDonald untuk Studi Islam dan Hubungan Muslim-Kristen, Abu Rabi' terkemuka sebagai spesialis sejarah pemikiran Islam. Ini tidak terlepas dari konsentrasi akademiknya di bidang studi Islam, agama-agama dunia, mistisisme, agama dan sosiologi, agama dan filsafat politik, ilmu politik, dan sejarah Timur tengah. Selain itu, di samping Bahasa Arab, Abu Rabi' mahir dan menguasai Bahasa Inggris, Perancis, Persia, bahkan Ibrani. Tidak mengherankan jika kompetensi yang dimilikinya kemudian melahirkan berbagai karya terkait problematika pemikiran Islam kontemporer, studi agama-agama dan studi Islam.

Di samping disertasinya yang berjudul "Islam and Search for Social Order in Modern Egypt: An Intellectual Biography of Shaykh al-Azhar 'Abd Halim Mahmud", Abu Rabi' terhitung sebagai penulis prolifik dengan karya-karya yang begitu kontributif. Di antara karya-karya yang pernah ditulisnya adalah: (1) Buku: Work in Progress Neolibralism and Its Discontent: Studies in Post-1967 Arab Thought; Intellectual Origins of Islamic Resurgrnce in The Modern Arab World (New York: State University Of New York Press, 1996); Islamic Resurgence and The Challenge of The Contemporary World: A Round-Table Discussion with Professor Khurshid Ahmad (Tampa: The World and Islam Institute, 1995); The Pearls of Wisdom by the North African Mystic Ibn al-Sabbagh (Albany: State University of New York Press); The Blackwell Companion to Contemporary Islamic Thought (Oxford: Blackwell Publishing, 2006); Contemporary Arab Thought: Studies In Post-1967 Arab Intellectual History (London: Pluto Press, 2004) . (2) Artikel: A Post September 11 Critical Assesment of Modern Islamic History (2002); Between Sacred Text and Cultural Constructions: Modern Islam as Intellectual History (2000); Arabism, Islamism, and The Future of The Arab World: A Review Essay (2000); Globalization: A Contemporary Islamic Response? (1998); An Islamic Response to Modernity (1998), dan beberapa karya lainnya.

Jika dilihat dari karya-karyanya, jelas terkesan Abu Rabi' lebih tertarik mengkaji Islam dari prespektif historis-empirik. Abu Rabi' tidak lagi tertarik untuk melalukan ide-ide pembaharuan yang bersifat normatif-dogmatis yang berlandaskan pada teks keagamaan. Setidaknya, ini merupakan cermin awal untuk mengungkap kegelisahan akademik yang ia temui. Ada beberapa persoalan yang sebenarnya ingin disampaikan oleh Abu Rabi' terkait kondisi Islam saat ini di antaranya 
Islam vis a vis Kenyataan Dunia Kontemporer: A Contemporary Islamic Response

Saat ini, umat manusia memasuki sebuah era yang sulit untuk didefinisikan, sebuah dunia "tanpa batas". Tercatat pasca renaissance dan revolusi industri yang terjadi di Eropa dan Amerika, nyaris perkembangan sistem ekonomi, politik, dan sosial begitu bergeliat, khususnya di Dunia Barat. ${ }^{5}$ Modernisasi di berbagai aspek serta capaian yang menakjubkan di bidang ilmu pengetahuan dan teknologi menjadikan Dunia Barat (baca: Eropa dan Amerika) sebagai pionir sekaligus prototipe di pelbagai belahan dunia. Capaian atau kemajuan ini kemudian secara perlahan melakukan penetrasi dan penguasaan terhadap berbagai budaya, tidak terkecuali budaya Islam. Budaya materialisme dan liberalisme menjadi arus deras yang sulit dihentikan dan dianggap sebagai upaya imperialisme dan kolonialisme model baru.

Menghadapi kenyataan tersebut, respon umat Islam tidaklah sama ataupun senada, tetapi beragam dan bervariasi. ${ }^{6}$ Abu Rabi' mencatat bahwa setidaknya pada abad ke-18 dan ke-19 terdapat berbagai reaksi terhadap kejayaan Eropa. Respon umat Muslim pada kurun waktu itu terbagi pada tiga kategori:

\section{Modernisasi}

Modernisasi yang dilakukan oleh umat Islam ditandai dengan perjuangan Dinasti Utsmani untuk melakukan berbagai pembaharuan di kerajaannya.

${ }^{5}$ Istilah renaissance (pencerahan) menunjukkan sikap negatif dan diferensial kepada era sebelumnya (abad kegelapan). Satu hal yang perlu ditegaskan bahwa pencerahan adalah bukan gerakan terorganisir. Norman Hampson menyatakan bahwa pencerahan adalah sebuah sikap nalar dibandingkan sebuah bagian dari ilmu pengetahuan dan filsafat. Pencerahan adalah suasana hati yang kuat dalam berpikir bebas, bertanya kritis, sebuah suasana hati yang tersebar di dunia Barat sejak abad ke-17. Di dalam bidang ilmu pengetahuan pencerahan adalah sebuah masa dan penemuan melalui pencarian rasional bebas. Di dalam bidang filsafat dan agama pencerahan adalah masa mempertanyakan sumber-sumber otoritas tradisional seperti gereja atau Bibel. Di dalam politik pencerahan adalah sebuah periode ketika tatanan yang mapan, status quo, ditolak di mana despolitik dan irasional digantikan dengan toleransi, penelitian terbuka dan kebebasan. Tidak ada lagi ide-ide yang dianggap suci atau melampaui bentangan kritisme. Max Horkheimer dan Theodor W. Adorno, Dialectic of Enlightenment, terj. Ahmad Sahidah (Yogyakarta: IRCiSoD, 2002), h. 5.

${ }^{6}$ Dalam salah satu pengantar bukunya, Abu Rabi' menulis dengan tema Contemporary Islamic Tought: One or Many?. Pada pengantar tersebut, ia meyakinkan bahwa respon umat Islam terhadap dunia kontemporer ini sangatlah bervariasi. Respon variatif ini tidak terlepas dari kompleksitas problematika yang dihadapi umat Islam baik dari aspek politik, ekonomi dan sosial. Selain itu, sejarah intelektualitas umat Islam sangat mempengaruhi model dan tipikal pemahamannya atas tantangan globalisai tersebut. Baca: Ibrahim M. Abu Rabi' (ed), The Blackwell Companion to Contemporary Islamic Thought (Oxford: Blackwell Publishing, 2006), h. 2-3. 
Pelopor modernisasi di Turki adalah para elit politik, birokrat, intelektual serta ulama. Keterlibatan ulama dalam modernisasi tidak terlepas dari upayanya dalam menjaga umat. Namun demikian, modernisasi ini tidak seutuhnya berhasil karena tidak dapat mencegah runtuhnya otoritas politik Dinasti Utsmani pada akhir Perang Dunia I (1914-1918). Akan tetapi, sebelum keadaan menjadi lebih buruk, para intelektual Turki mulai mengadopsi westernisasi dan sekulerisasi sebagai solusi selanjutnya.

Program modernisasi yang terkenal dengan nama tanzimat digalakkan oleh pemerintah pusat dalam menghadapi ancaman Eropa. ${ }^{7}$ Tanzimat ini diadopsi untuk dijadikan kebijakan modernisasi secara top-down. Untuk menyelamatkan Turki, satu-satunya jalan adalah memahami betul wacana nasionalisme, sekularisme, dan modernisasi. Bagi Muslim dengan tipologi ini, modernisasi adalah keharusan dalam menjawab berbagai ketertinggalan umat Islam saat ini.

\section{Nasionalisme}

Nasionalisme merupakan ide dan semangat yang dikobarkan pada fase kedua abad ke-19 sebagai respon atas kesulitan dunia Muslim menghadapi tantangan dan perkembangan bangsa Eropa. Merujuk pada pendapat Anderson, Nasionalisme diartikan oleh Abu Rabi' sebagai pandangan tentang negara yang terbatas, tidak seperti pandangan tentang keumuman sebagaimana yang muncul dalam tradisi Kristen (Christendom) dan Islam (Ummah). Abu Rabi' menegaskan bahwa gerakan-gerakan nasionalisme inilah yang menggiring bangsanya berjuang melawan penjajahan meskipun pada faktanya mereka sama sekali tidak memakai jargon-jargon agama dalam pidato atau orasi kebangsaannya. Contoh gerakan nasionalisme ini adalah yang dipimpin tokoh-tokoh seperti: Soekarno di Indonesia, Kemal Attaturk di Turki, Mohammad Ali Jinnah di Pakistan dan Gamal Abd al-Naser di Mesir. ${ }^{8}$

${ }^{7}$ Tanzimat adalah suatu gerakan pembaharuan di Turki yang awalnya adalah modernisasi di tubuh Turki Usmani, yang terpenting adalah modernisasi dalam kemiliteran dan kecendrungan elit birokrasi untuk meniru gaya hidup kelas atas di Barat akibat ketertarikan atas masyarakat sipil Barat. Program ini dilakukan oleh Mustafa Rasyid Pasya dan Mehmed Sadik Risyad Pasya yang kemudian diikuti dengan lahirnya piagam Humayun, yang berisi tentang kedudukan orang Eropa, Usmani Muda, dan Turki Muda. Gerakan ini kemudian melahirkan pembaharuan yang dilakukan di bawah pimpinan Mustafa Kemal Attaturk. Baca: John L. Esposito (ed), The Oxford Encyclopedia of The Modern Islamic Word, vol. 4 (New York: Oxford University Press, 19995), h. 183-185.

${ }^{8}$ Ibrahim M. Abu Rabi', "A Post Critical Assesment of Modern Islamic History" dalam Ian Markham dan Ibrahim M. Abu Rabi', 11 September: Relegious Perspectives on The Causes and Concequences (Oxford: Oneworld Publications, 2002), h. 24-25. 
Untuk melawan imperialisme, nasionalisme diarahkan pada dua hal, spiritual dan institusional. Secara spiritual, nasionalisme berupaya mencari kepastian akan kedaulatan negara, masa lalu dan identitas budaya. Sedangkan secara institusional, nasionalisme berusaha membangun negara dengan belajar ilmu pengetahuan Barat dan pembangunan institusi Barat. Kedua fungsi nasionalisme ini diadopsi Abu Rabi' dari Partha Chatterjee.

Revivalisme Islam

Revivalisme Islam merupak bentuk respon lain atas tantangan kolonialisme. Menurut Esposito, ihya' (menghidupkan) dan tajdid (pembaharuan) adalah dua kata kunci dalam revivalisme Islam. Menurut kelompok dengan faham ini, Islam bukanlah masalah, artinya bahwa kemunduran dan stagnansi dunia Islam bukan disebabkan oleh Islam, bahkan sebaliknya Islam adalah solusi. Stagnansi yang terjadi di dunia Islam lebih disebabkan karena umat Islam tidak mau berpegang teguh pada ajaran Islam. Oleh karena itu, kembali kepada Islam adalah seruan sekaligus jalan satu-satunya untuk mengembalikan kejayaan Islam.

Abu Rabi' membagi revivalisme Islam menjadi empat periode: (1) Prakolonial, ditandai dengan gerakan Wahabi pada awal abad ke-18 yang berfokus pada usaha-usaha pemurnian Islam di bidang hukum Islam dan teologi; (2) Kolonial, seperti Muhammadiyah dan Nahdhatul Ulama di Indonesia yang berdiri pada abad ke-20, serta al-Ikhwan al-Muslimun pada 1928 di Mesir dan Jama'ah Islamiyah di India. Gerakan atau organisasi era ini bergerak dalam kemajuan pendidikan dan perlawanan terhadap penjajah; (3) Pasca-kolonial, terbentuknya bangsa-bangsa di Dunia Muslim pada pertengahan abad ke-20 adalah penyebab terbantuknya gerakan pada era ini. Gerakan jihad di Mesir tahun 1970-1980 misalnya, berupaya merefleksikan interpretasi ekstrem agama dan mengambil jalan kekerasan untuk mendapatkan maksud dan tujuannya; (4) Pasca-nation-state, diwakili oleh gerakan Taliban dan al-Qaeda, gerakan ini bertujuan untuk mengakhiri kekerasan dan kerusuhan dalam negeri, menghentikan segala bentuk intervensi asing dan memulihkan martabat masyarakat sipil meskipun terkadang dengan menggunakan cara-cara yang keras.

Berbagai respon umat Islam atas kemajuan dan kolonialisme Eropa seperti tersebut di atas sebenarnya merupakan potret bagaimana umat Islam secara sosio-politik berusaha untuk meraih kebangkitan sebagaimana yang dicitacitakan. Bagi Abu Rabi' kebangkitan Islam di tangan gerakan-gerakan tersebut di atas menjadi problematis ketika mereka tidak mampu memosisikan dan membedakan ranah kebangkitan tersebut. Apakah kebangkitan Islam bersifat 
Millatī, Journal of Islamic Studies and Humanities, Vol. 1, No. 1, Juni 2016: 23-39

doktrinal, filosofis, atau historis-politis? ${ }^{9}$ Tema sentral ide pembahuruan pemikiran dalam Islam terletak pada kata kunci i'adatul Islam, yakni keinginan masyarakat Muslim untuk mengembalikan peran dunia Islam dalam percaturan global peradaban dunia. ${ }^{10}$

Berbeda dengan Abu Rabi', al-Jabiri menganggap bahwa keterpurukan bangsa Arab (baca: umat Islam) dan gagalnya upaya kebangkitan Islam pada umumnya, disebabkan oleh gagalnya menemukan cara yang tepat dalam menyikapi dan mendudukkan warisan tradisi (turats) dalam arus modernisasi. Selama ini, terdapat tiga tipologi pembacaan turats menurut al-Jabiri: pertama, pembacaan tradisi dari kaca mata tradisional (al-fahm al-turâtsi li turâts). ${ }^{11}$ Kedua, pembacaan tradisi ala orientalis. ${ }^{12}$ Dan ketiga, pendekatan Marxis yang mengandaikan adanya dialektika-historis-materialis antara gugusan ide-ide dengan realitas konkret. ${ }^{13}$ Terlepas dari perbedaan tipologi di antara keduanya, baik Abu Rabi' maupun al-Jabiri bertemu dalam satu garis persamaan, yakni berupaya menyingkap kondisi dan respon umat Islam terhadap modernisasi

${ }^{9}$ Ibrahim M. Abu Rabi', Intellectual Origins of IslamicResurgence in The Modern Arab World (New York: State University Of New York Press, 1996), h. 10.

${ }^{10}$ Sebelumnya, Muhammad Abduh menjadikan Tajdid al-Fahm (memperbaruhi pemahaman Islam) sebagai kata kunci dalam pola pemikirannya, Rasyid Ridha mempunyai konsep Tathbiq al-syari'ah, atau Tathbiq qanun al-Syari'ah. Konsep-konsep tersebut disiapkan untuk menyembuhkan penyakit imperialisme-kolonialisme yang membelunggu umat Islam, yakni dengan cara mengaplikasikan kembali atau mempraktikkan kembali materi undang-undang dan tatacara kenegaraan yang pernah dilakukan oleh generasi Muslim terdahulu. Lihat: Hasan Mahfudh, Rasyid Ridha; "Arah Baru Paradigma Kritik Hadis", dalam Muammar Zayn Qadafy, Yang Membela dan Yang Menggugat (Yogyakarta: Interpena, 2011), h. 41. Bandingkan: Amin Abdullah, Islamic Studies di Perguruan Tinggi; Pendekatan Integratif-Interkonektif (Yogyakarta: Pustaka Pelajar, 2006), h. 250-251.

${ }^{11}$ Karakteristik pembacaan tradisional adalah tautologis (qira'ah tikrar), tidak produktif (ghayr muntijah), ahistoris dan melulu mencomot pendapat-pendapat ulama klasik tanpa kritisisme. Ekses dari tipologi pembacaan tradisional adalah selalu menundukkan kompleksitas problem kekinian di bawah hegemoni nilai-nilai kuno. Dengan model pembacaan ini, kaum tradisional hendak menuai Islam otentik (al-ashalah), tetapi, tanpa bisa dihindari, justru gagap menghadapi tantangan-tantangan modern (hadâtsah) dan kontemporer (mu'âshirah). M. Abed al-Jabiri, alTurats wa al-Hadatsah, h. 26.

12 Pendekatan yang digunakan dan ditawarkan oleh orientalis adalah filologi dan historisisme. Teori-teori ini telah mengantarkan mereka pada konklusi-yang tentu masih debatable-bahwa khazanah intelektual Islam hanyalah copy paste dari tradisi pemikiran Yunani, Persia, India dan lain-lain. M. Abed al-Jabiri, al-Turats wa al-Hadatsah, h. 26.

${ }^{13}$ Dalam pendekatan ini, tradisi pemikiran Islam dipandang sebagai produk dialektika antara teks-teks keagamaan dengan realitas sosio-historis yang terjejali oleh fenomena pertentangan ekonomi antara kelas borjuis vis a vis proletar. M. Abed al-Jabiri, al-Turats wa al-Hadatsah, h. 27. 
Barat. Jika al-Jabiri tertarik melakukan perhatian dari sisi sikap terhadap turats, maka Abu Rabi' lebih meilihat sisi sosial-politik umat Islam. Artinya, ketertinggalan umat Islam atas Barat bukanlah suatu hal imajiner, tetapi merupakan fakta sekaligus tantangan yang sampai saat ini harus diselesaikan.

\section{Krisis Perspektif dan Metodologi dalam Studi Islam}

Ketika menelisik problematika studi Islam, Abu Rabi' kembali menegaskan pentingnya distingsi antara Islam dan pemikiran Islam atau studi Islam itu sendiri. Dengan merujuk pada pendapat Ibnu Khaldun, Abu Rabi' meyakini bahwa studi Islam berbeda dengan Islam. Jika Islam merujuk kepada wahyu yang kekal dan agama yang suci, maka pemikiran atau studi Islam merujuk pada seluruh perkembangan ilmu pengetahuan Muslim seperti penafsiran alQur'an, hadis, fikih, kalam, sufi dan sebagainya. Dalam arti bahwa pemikiran dan studi Islam senantiasa terbuka, berubah (qabil li al-taghyir), dan selalu siap untuk dikritisi serta dikembangkan.

Selanjutnya hal ini berarti bahwa pemikiran atau studi Islam sangat dipengaruhi oleh tingkat kemajuan peradaban manusia itu sendiri. Jasser Auda misalnya memberikan gambaran yang cukup jelas tentang tiga varian pola pemikiran epistemologi studi Islam dengan berbagai karakter masing-masing; Islamic traditionalism, Islamic modernism, dan post-modernism. ${ }^{14}$ Ciri pokok Islamic traditionalism terletak pada paham teleologi yang bergeser pada teologi. Jika paham teleologi mengharuskan segala sesuatu dinilai dari tujuannya, maka dalam pandangan Islamic traditionalism tujuan ini harus dinilai secara teologis. Dalam konteks studi Islam maka baik dan buruknya segala sesuatu harus dinilai dari tujuan teologis (Allah). Sehingga, teks menjadi sentral dalam studi ini. ${ }^{15}$

Epistemologi tekstual yang digunakan Islamic Traditionalism pada selanjutnya dikritik oleh Islamic Modernism. Bagi kaum modernis Islam, teologi terlihat sebagai ide yang menghambat kemajuan ilmu pengetahuan. Perkemba-

\footnotetext{
${ }^{14}$ Jasser Auda, Maqasid al-Shari'ah as Philosopy of Islamic Law: A Systems Approach (London: The International Institute of Islamic Thought, 2008), h. 17.

${ }^{15}$ Adonis memberikan beberapa kriteria sentralitas teks pada studi ini; (1) otoritas, (2) kebenaran tidak terdapat di dunia, manusia, atau alam, tetapi ada dalam teks, (3) pemahaman terhadap realitas harus sejalan dengan teks, (4) anti kritis, maksudnya menekankan pemikiran dogmatis misionaris-praktis moralis, (5) kebangkitan adalah kembali pada teks dasarkebenaran berada di kekuasaan sebagai penjaga teks dan bahwa kebenaran adalah satu sehingga tidak ada pluralitas dan perbedaan. Adonis, al-Tsabit wa al-Mutahawwil: Bahts fi al-Ibda wa al-Itba' 'inda alArab, terj Khairon Nahdiyyin, Jilid I (Yogyakarta: LKiS, 2007), h. XXXV.
} 
ngan kimia, geometri, dan astronomi lebih lanjut memberikan angin segar bagi dunia ilmu pengetahuan. Logika kausalitas mulai memainkan peran 'logis' dan mendominasi metode berpikir. Modernisme Islam yang pada umumnya reaksi terhadap modernisme Eropa menegaskan bahwa pemikiran Islam lebih siap untuk ide kausalitas daripada pemikiran lainnya. Modernis Islam bekerja dalam kerangka ilmu pengetahuan modern dan konsep kausalitas untuk menafsirkan kembali atau membaca ulang filsafat Islam dari agama. Sehingga modernis sedikit demi sedikit memahami bahwa teori, perilaku alam berada pada lingkaran logika dan ilmu pengetahuan. Segala hal yang diluar lingkaran logika dan ilmu pengetahuan dianggap menghambat dan harus ditolak. Jelas bahwa pada epistemologi ini ilmu pengetahuan menjadi sentral dalam kajian.

Setelah ditemukan berbagai kelemahan pada corak pemikiran modernis, beberapa pemikir yang tersemasuk pada kategori Islamic post-modernism menawarkan alternatif lainnya. Ciri utama pemikiran post-modernisme terletak pada penerimaannya terhadap berbagai hal dan fenomena-fenomena di luar logika dan ilmu pengetahuan. Hal ini tidak terlepas dari keterpengaruhan mereka terhadap teori dekonstruksi Derrida. Teori ini meniscayakan kehancuran adanya "sentral" dalam berbagai hal. Terdapat tiga prinsip pada epistemologi ini: (1) prinsip kebebasan berkreasi tanpa batas, (2) prinsip ketidakberhinggaan pengetahuan, ketidakberhinggaan eksplorasi, dan (3) prinsip kelainan, perbedaan dan pluralitas. ${ }^{16}$

Dihadapkan pada tiga epistemologi tersebut, Abu Rabi' lantas mempertanyakan kondisi studi Islam dewasa ini. Meskipun beberapa negara Muslim telah merdeka, seperti Mesir, Indonesia, dan Pakistan, modernisasi di bidang studi Islam dapat dikatakan kurang memadai -untuk tidak mengatakan tidak memadai sama sekali. Gejala-gejala keterbelakangan itu tampak dari berbagai aspek; pertama, para elit militer dan politikus aktif memberi dukungan kepada lembaga-lembaga pendidikan tradisional hanya untuk mempertahankan status quo. Terdapat semacam simbiosis mutualisme anatara pendidikan dan kekuasaan.

Kedua, Sentralitas dan sensitifitas Islam. Negara dengan jelas mengintervensi konstruksi modern studi-studi keIslaman untuk menjamin netralitas agama dalam problem sosial dan politik. Sehingga studi Islam terbatas pada retorika dan tata bahasa Arab.

\footnotetext{
${ }^{16}$ Adonis, al-Tsabit wa al-Mutahawwil: Bahts fi al-Ibda wa al-Itba' 'inda al-Arab, h. XXXV.
} 
Ketiga -dan ini adalah gejala utama-, perspektif ilmu sosial dan filsafat tidak ada. ${ }^{17}$ Pengalaman pribadi Abu Rabi' sendiri menunjukkan bagaimana ilmu-ilmu sosial tidak mendapatkan tempat di kalangan umat Islam. Bahkan, ilmu-ilmu sosial tersebut dianggap sebagai bid'ah sehingga jarang sekali ditemukan mahasiswa -khususnya dari Teluk-yang melanjutkan studi di bidang ilmu sosial. Dalam pada itu Abu Rabi' menyatakan:

The absence of social science or critical philosophy perspectives from the field of Shari'ah studies can be illustrated by the fact that most students who acquire a government scholarship to pursue their graduate education abroad, especially from the Gulf states, study only the hard sciences or business administration, supposedly value-free or cricismfree subjects. In my many years in the United States (almost twenty years now), I have never encountered a single student from the Gulf pursuing a graduate degree in political science, philosophy, or history. Closing the door to any type of critical perspective has been the underpinning of the field of Religious Studies (especially Islamic Studies) and made it quite irrelevant. This fact has made it quite difficult in many Arab countries to encourage the growth of a scientific tradition, developed mainly in the West, to study the complex interplay between religion and society in the modern Arab world. The discipline of the sociology of religion is looked upon as bid'ah, or innovation, that does not convey the real essence of Islam. Just like the study of the modern Arab state system, the sociology of religion is a necessity in the Arab world. ${ }^{18}$

Keempat, studi Islam hanya berputar pada kajian syari'ah dan fikih yang kosong dari kritik politik, serta kosong dari relevansi situasi kekinian. Mengomentari kenyataan ini, Abu Rabi' menyetir pendapat Malek Bennabi dengan mengatakan: "dalam lembaga-lembaga Muslim independen, silabi, dan metode pengajaran seperti membuang-buang waktu. Prinsip-prinsipnya sama sejak abad pertengahan umat Kristen.

Kelima, terdapat pembedaan yang sangat jelas antara teologi dan politik atau teologi dan sosial. Teologi dipahami sebagai ritus, simbol dan hanya berupa teks-teks sejarah. Hal ini menimbulkan ketegangan antara pemikiran dan realitas, antara Islam dan realitas. Bagi Abu Rabi' kondisi kelima ini mencipta-

${ }^{17}$ Hasan Hanafi memberi perhatian khusus tentang absennya tema-tema yang berkaitan dengan kemasyarakatan (sosial) dan kemanusiaan dalam studi Islam tradisional. Dalam akhir karyanya Dirasat Islamiyyah, Hanafi membahas secara spesifik persoalan ini. Bagi Hanafi, turas ataupun studi Islam klasik terlalu mengabaikan sunjek pengkaji dalam hal ini manusia. Manusia seakan hilang dan dianggap tidak terdifrensiasi dengan teks. Baca: Hasan Hanafi, Dirasat Islamiyyah (Kairo: Maktabah Anglo, tt), h 393.

${ }^{18}$ Ibrahim M. Abu Rabi', "A Post Critical Assesment of Modern Islamic History”, h. 36. 
kan kelas intelektual Muslim yang terbelakang dalam masyarakat. Mereka paham betul teks-teks Islam tetapi tidak mengerti bagaimana menguji teks-teks secara kritis dalam kaitannya dengan kondisi sosial dan politik di sekitarnya.

Kondisi studi Islam diperparah dengan langgengnya intelektual yang dikontrol oleh negara hanya untuk mencari kesenangan dengan mendiskusikan persoalan-persoalan teologi yang sangat sepele atau mengangkat pertanyaanpertanyaan yang telah mati ratusan tahun lalu. Intelektual Islam buta dan tidak peka terhadap permasalahan di sekitarnya. Mereka lebih tertarik pada problem otentisitas ajaran daripada problem riil masyarakat. ${ }^{19}$ Sistem yang menekankan hafalan sebagai menu harian mendorong terciptanya kultur berbasis teks. Akan tetapi, bagaimanapun juga terdapat fakta ditemukannya sejumlah kecil intelektual berpendidikan tradisional yang menentang rezim berkuasa. Hanya saja, penggunaan teks-teks suci sebagai senjata ideologi di tangan negara untuk melawan mereka yang mencoba mengritik negara dan pendukungnya.

Di sisi lain, Abu Rabi' menemukan bahwa sistem pendidikan sekuler di negeri-negeri Muslim juga tidak lebih baik dari sistem tradisional. Abu Rabi' mengamini pendapat Ishtiaq Qureshi yang mengritik pedas elit terpelajar sekuler Pakistan dengan mengatakan: "elit terpelajar sekuler kita adalah orang yang tidak mempunyai kemandirian sikap, tidak mengindahkan moral, dan hanya intelektual upahan.”

Singkatnya, Abu Rabi' memandang kondisi studi Islam saat ini cukup memprihatinkan dan dalam keadaan krisis. Perspektif yang digunakan masih terkesan dikotomis, berpusat pada teks. Tema ataupun persoalan yang diangkat cukup usang (expired) bahkan buruk (ugly) dan jauh dari persoalan kekinian. Hal ini terjadi tidak hanya karena ketertinggalan peradaban keilmuan umat Islam, tetapi juga disebabkan oleh intelektual-intelektual Islam yang gagal terlibat aktif dalam memberikan solusi atas berbagai problem kontemporer.

${ }^{19}$ Hasan Hanafi menyebut intelektual macam ini dengan “jamahir”. Bagi Hanafi, jamahir sama sekali tidak dapat diandalkan dalam modernisasi pemikiran Islam. Kegandrungan dalam mendukung status quo pemerintah berkuas membuat objektivikasi keilmuan tidak didapatkan. Bahkan, ideologi pembaharuan sama sekali tidak demiliki oleh mereka demi kemapanan yang telah menggurita. 


\section{Multidisiplin dalam Studi Islam; Sebuah Tawaran Kongkrit}

Tawaran kongkrit Abu Rabi' terhadap problematika dan krisis metodologi dalam studi Islam sebagaimana tersebut di atas (baca: sub sebelumnya) setidaknya terdapat pada dua hal. Pertama, Abu Rabi' menyadarkan bahwa studi atas Islam tidak dapat dilakukan dalam satu aspek saja. Menurut Abu Rabi' setidaknya terdapat empat aspek dalam Islam: (1) Aspek filosofis atau ideologis. Pada dataran ini Islam menjadi problem filsafat dan ideologi dalam pemikiran Arab-Islam. (2) Aspek teologis. Pada tataran ini Islam memiliki maknanya yang terbuka. Islam dapat dilihat dari teologi inklusif, yaitu keesaan Tuhan. (3) Aspek teks (nash). Teks adalah inti pokok kebudayaan Islam, ia tidak lahir dari ruang hampa, tetapi senantiasa berdialektika dengan realitas sejarah kebudayaan manusia. Dengan demikian harus dipahami secara dialektis antara teks dan realitas serta antara teks dan penafsiran manusia. Sejarah dan pemikiran Muslim merupakan perpaduan kompleks antara yang bersifat manusia (humane) dan yang bersifat ketuhanan (divine). (4) Aspek realitas antropologis. Selain memiliki sisi normatif, dalam Islam telah terjadi evolusi perkembangan kesejarahannya. Islam telah mendorong lahirnya dinamika kultural, sosial, dan politik yang kompleks. ${ }^{20}$

Mengingat bahwa Islam tidak lepas dari aspek-aspek tersebut (bahkan bisa lebih atau ditambahkan), maka pemikiran atau bahkan studi Islam harus menyentuh berbagai aspek tersebut. Studi Islam tidak dapat dilakukan hanya dengan satu aspek saja, teks misalnya. Kesaling-terkaitan antara aspek-aspek tersebut kemudian membuka peluang yang lebar bagi penggunaan ilmu-ilmu sosial, filsafat, politik, dan ilmu-ilmu lainnya dalam memahami Islam. Monodisiplin keilmuan dalam studi Islam harus secepatnya ditinggalkan. Perkembangan ilmu-ilmu dewasa ini sangat membantu kekayaan perspektif dalam studi Islam. Sehingga, inter-disiplin atau multidisiplin merupakan tawaran kongkrit dalam mengurai benang kusut studi Islam saat ini. Kesaling terkaitan aspekaspek dan keterbukaan atas ilmu sosial-humaniora dapat digambarkan sebagaimana berikut:

${ }^{20}$ Ibrahim M. Abu Rabi', "A Post Critical Assesment of Modern Islamic History”, h. 33 34. 


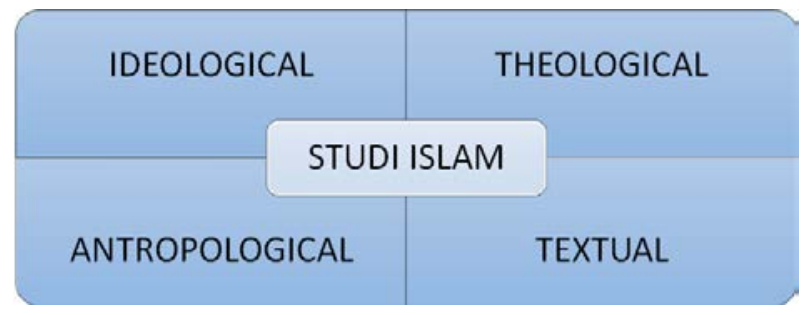

Kedua, Abu Rabi' menginginkan lahirnya intelektual yang betul-betul terlibat dalam membangkitkan studi Islam dan berupaya keras mengatasi problem umat Islam kontemporer. Dalam tradisi keilmuan, intelektual tersebut biasa disebut dengan intellectual engagement. Tugas utama dari intelektual model ini adalah berupaya sekuat tenaga tidak terkait dengan kepentingan penguasa dalam mempertahankan status quo. Intelektual dengan semangat objektivikasi keilmuan dan berusaha menjadi problem solving dalam tantangan kehidupan umat Islam saat ini.

\section{Refleksi Atas Pemikiran Ibrahim M. Abu Rabi’; Ilmu Sosial-Humaniora dalam Studi Hadis}

Secara filosofis, setidaknya terdapat dua alasan utama yang menjadikan pendekatan ilmu-ilmu sosial "mungkin" untuk diaplikasikan dalam pemahaman hadis ${ }^{21}$; pertama, hadis mencakup beragam persoalan. Hadis-hadis nabi tidak hanya berkaitan dengan persoalan keagamaan (baca: 'ubudiyyah) saja, akan tetapi terdapat beberapa bahkan banyak problematika yang berkaitan dengan sosial, kesehatan, politik, ekonomi dan sebagainya. Kedua, dalam memahami hadis, para ulama cenderung memfokuskan pada riwayat dengan menekankan kupasan dari segi gramatika bahasa (baca: tekstual). ${ }^{22}$ Padahal, terdapat beberapa aspek yang mestinya diperhatikan di luar aspek kebahasaan.

${ }^{21}$ Pada dasarnya hadis adalah kumpulan sikap manusia di mana kesadaran nabi bekerja. Ia melaksanakan peran penentu hukum bagi realitas yang mungkin berdasarkan wahyu awal, wahyu baru atau berdasarkan pada pemahaman otomatis nabi atas realitas. Pada konteks inilah signifikansi analisis sosio-historis terhadap hadis tampak jelas dan penting. Lihat: Hasan Hanafi, Al-Turas wa al-Tajdid, terj Yudian Wahyudi (Yogyakarta: Titian Ilahi Press, 2001), h. 197.

22 Bandingkan dengan pendapat Suryadi yang menyatakan bahwa fakta tidak semua kitab hadis terdapat syarahnya merupakan faktor mendasar dari pentingnya pendekatan yang komperhensif dalam pemahaman hadis. Lihat: Fazlur Rahman (dkk), Wacana Studi Hadis Kontemporer (Yogyakarta: Tiara Wacana, 2002), h. 140. 
Pendekatan ilmu-ilmu sosial dalam pemahaman hadis saling terkait dengan upaya pemilahan posisi nabi sebagai author teks. Upaya pemilahan ini sebenarnya telah dilakukan oleh beberapa ulama atau pemikir hadis sebelumnya. Al-Qarafi ulama mazhab Maliki yang hidup pada abad ke-tujuh Hijriyah memilahnya menjadi tiga fungsi yaitu pertama sebagai penyampai risalah, maka apa yang nabi sampaikan dalam kapasitas ini akan menjadi hukum yang universal, yang kedua sebagai pemimpin maka konsekuensinya tidak ada orang yang boleh melakukannya kecuali seizin pemimpin sesuai dengan perbuatan Rasulullah, ketiga apa yang Nabi lakukan dalam kapasitas sebagai hakim, maka konsekuensinya tidak ada seorangpun yang boleh melakukannya kecuali dengan perintah dari hakim. ${ }^{23}$

Konsekuensi difrensiasi teks hadis dengan melihat posisi Nabi sebagai pengujar sekaligus pemilik teks -sebagaimana di atas-adalah terbukanya berbagai macam perspektif ataupun pendekatan yang memungkinkan dalam memahami teks hadis tersebut. Tentunya, perspektif-perspektif tersebut lahir dan dikenal dalam sebuah disiplin keilmuan yang mengakar. Artinya, perspektif sosiologis misalnya dapat digunakan dalam pemahaman hadis dengan menggunakan satu ataupun beberapa teori sosial yang dianggap sesuai terhadap muatan teks hadis. Teks hadis yang berisi pelajaran berwirausaha sangat memungkinkan untuk dipahami dengan teori-teori ekonomi, dsb. Adalah sebuah keniscayaan jika suatu hadis dipahami dengan transperspektif maupun multiperspektif.

Untuk menyukseskan keterbukaan studi hadis atas ilmu-ilmu sosialhumaniora, maka pemikiran inspiratif Abu Rabi' dapat diadopsi dan dikembangkan. Jika dalam Islam terdapat empat aspek yang selalu melingkupi, maka hadis sebagai mozaik Islam juga memiliki aspek-aspek tersebut: ideologi, teologi, teks, dan antropologi. Dalam menyikapi hadis, seseorang tidak harus melulu memahaminya dalam tataran tekstualitasnya, tetapi dapat dipahami dari aspek-aspek lainnya, antropologi misalnya. Sehingga, dalam studi hadis tidak hanya terpaku pada kajian atas persoalan sanad dan matan, tetapi dapat dikembangkan dengan kajian atas ideologi hadis, antropologi hadis dan sebagainya. Peta penelitian hadis selanjutnya bergeser dan berkembang pada arah studi hadis kontemporer:

${ }^{23}$ Yusuf Qardawi, Sunnah Rasul Sumber Ilmu Pengetahuan dan Peradaban, Terj. Abdul Hayyi al-Kattani dan Abduh Zulfidar, (Jakarta: Gema Insani Press, 1998), h. 50-55 


\begin{tabular}{lll}
\hline & Studi Hadis Tradisional & Studi Hadis Kontemporer \\
\hline Jenis Penelitian & - Kualitatif & - Kualitatif \\
& - Kuantitatif & - Kuantitatif \\
\hline Objek Penelitian & - Sanad & - Tekstualitas hadis \\
& - Matan & - Ideologi hadis \\
& & - Antropologi hadis \\
& & - Teologi hadis \\
\hline Metode & - Tahlili & - Dsb \\
\hline Pendekatan & - Maudhu'i & - Intertekstualitas \\
& - Tekstual & - Tematik-interpretatif \\
\hline & - Kontekstual & - Tekstual-ideological \\
& & - Antropologi-tekstual \\
\hline
\end{tabular}

\section{Kesimpulan}

Dari pembahasan di atas dapat disimpulkan bahwa: pertama, kegagalan umat Islam dalam menghadapi tantangan perkembangan dunia keilmuan kontemporer menyisakan pekerjaan rumah yang tidak mudah. Studi Islam dituntut untk menawarkan berbagai solusi dalam menghadapi problematika saat ini. Abu Rabi' lantas menawarkan pembacaan multidisiplin dalam studi Islam. Kedua, dalam perjalanan sejarah pemikiran Islam, Abu Rabi' banyak menemukan intelektual yang hanya bekerja dan belajar dalam rangka menjunjung status qua pemerintah berkuasa. Intellectual engagement sangat penting dan perlu dilahirkan kembali dalam menjawab ide kebangkitan Islam. Ketiga, dengan memerhatikan aspek-aspek yang berkaitan dengan Islam, studi Islam dengan sendirinya sangat terbuka bagi disiplin-disiplin ilmu sosial, humaniora, politik dan sebagainya.

\section{Daftar Pustaka}

Abdullah, Amin. Islamic Studies di Perguruan Tinggi; Pendekatan IntegratifInterkonektif. Yogyakarta: Pustaka Pelajar, 2006.

Abu Rabi', Ibrahim M. "A Post Critical Assesment of Modern Islamic History" dalam Ian Markham dan Ibrahim M. Abu Rabi'. 11 September: Relegious Perspectives on The Causes and Concequences. Oxford: Oneworld Publications, 2002.

Ibrahim M. Intellectual Origins of IslamicResurgence in The Modern Arab World. New York: State University Of New York Press, 1996. 
, Ibrahim M. (ed). The Blackwell Companion to Contemporary Islamic Thought. Oxford: Blackwell Publishing, 2006.

Adonis. Al-Tsabit wa al-Mutahawwil: Bahts fi al-Ibda wa al-Itba' 'inda al-Arab, terj Khairon Nahdiyyin. Jilid I. Yogyakarta: LKiS, 2007.

Auda, Jasser. Maqasid al-Shari'ah as Philosopy of Islamic Law: A Systems Approach. London: The International Institute of Islamic Thought, 2008.

Bullock, Katherine (ed). "Neo-Orientalism \& Islamophobia: Post -9/11". American Journal Of Islamic Social Science. USA: International Institute of Islamic Though, 2004. Vol. XXI, No. 3.

Esposito, John L. (ed). The Oxford Encyclopedia of The Modern Islamic Word, vol. 4. New York: Oxford University Press, 19995.

Hanafi, Hasan. Al-Turas wa al-Tajdid, terj Yudian Wahyudi. Yogyakarta: Titian Ilahi Press, 2001. , Hasan. Al-Turats wa al-Tajdid cet. IV. Kairo: al-Mu'assasah al-Jami' iyah li al-Dirasat wa al-Nasyr wa al-Tauzi', 1992.

Hanafi, Hasan. Dirasat Islamiyyah. Kairo: Maktabah Anglo, tt.

Horkheimer, Max dan Theodor W. Adorno. Dialectic of Enlightenment. terj. Ahmad Sahidah. Yogyakarta: IRCiSoD, 2002.

Al-Jabiri, M. Abed. Al-Turats wa al-Hadatsah. Beirut: Markaz Dirasat al-Wihdah al-Arabiyah, 1991.

M. Abed. Nahnu wa al-Turats: Qira'ah Mu'ashirah fi Turatsina alFalsafi cet. VI. Beirut: al-Markaz al-Tsaqafi al-Arabi, 1993.

Mahfudh, Hasan. Rasyid Ridha; "Arah Baru Paradigma Kritik Hadis", dalam Muammar Zayn Qadafy. Yang Membela dan Yang Menggugat. Yogyakarta: Interpena, 2011.

Nasiruddin. "Metodologi Studi Agama Perspektif Arkoun dan Ibrahim M. Abu Rabi”, dalam M Arfan Mu'ammar (dkk). Studi Islam. Yogyakarta: IRCiSod, 2011.

Qardawi, Yusuf. Sunnah Rasul Sumber Ilmu Pengetahuan dan Peradaban, Terj. Abdul Hayyi al-Kattani dan Abduh Zulfidar. Jakarta: Gema Insani Press, 1998.

Rahman, Fazlur (dkk). Wacana Studi Hadis Kontemporer. Yogyakarta: Tiara Wacana, 2002. 